\title{
Dental luxation and avulsion injuries in Hong Kong primary school children
}

\author{
SY Cho *
}

\section{A B S T R A C T}

Objectives: To identify the major causes and types of dental luxation and avulsion injuries, and their associated factors in primary school children in Hong Kong.

Design: Case series.

Setting: School dental clinic, New Territories, Hong Kong.

Patients: The dental records of children with a history of dental luxation and/or avulsion injury between November 2005 and October 2012 were reviewed. Objective clinical and radiographical findings at the time of injury and at follow-up examinations were recorded using a standardised form. Data analysis was carried out using the Chi squared test and multinomial logistic regression.

Results: A total of 220 children with 355 teeth of dental luxation or avulsion injury were recorded. Their age ranged from 6 to 14 years and the femaleto-male ratio was 1:1.8. The peak occurrence was at the age of 9 years. Subluxation was the most common type of injury, followed by concussion.
This article was published on $17 \mathrm{Jul}$ 2015 at www.hkmj.org. affected teeth. The predominant cause was fall and most injuries occurred at school. Incisor relationship was registered in 199 cases: most of them were Class I. Comparison of the incisor relationship in study children and the general Chinese population in another study revealed a higher proportion of Class II and fewer Class III occlusions in the trauma group $(\mathrm{P}<0.0001)$.

Conclusion: Most dental luxation and avulsion injuries in Hong Kong primary school children are caused by fall. Boys are more commonly affected than girls, and a Class II incisor relationship is a significant risk factor.

\section{Hong Kong Med J 2015;21:339-44}

DOI: $10.12809 / \mathrm{hkmj} 144433$

SY Cho *, MDS (Otago), FHKAM (Dental Surgery)

MacLehose Dental Centre, G/F, 286 Queen's Road East, Wanchai, Hong Kong

* Corresponding author: rony_cho@dh.gov.hk

New knowledge added by this study

- This is the first epidemiological study of traumatic dental injury in children residing in Hong Kong. The present findings provide an important baseline for future comparison.

Implications for clinical practice or policy

- As most injuries occur at school, it may be beneficial to educate primary school teachers about emergency care of children with dental trauma.

\section{Introduction}

Childhood injury is a major cause of death and disability in many countries, including Hong Kong. ${ }^{1}$ Although previous studies have reviewed general childhood injuries in Hong Kong children, ${ }^{1,2}$ dental injuries have not been specifically studied and reported. The oral region comprises $1 \%$ of the total body area, yet a population-based study in Sweden showed that it accounts for $5 \%$ of all body injuries at all ages. ${ }^{3}$ A recent study conducted by the Department of Health showed that injuries to orofacial areas accounted for $1.7 \%$ of all body injuries in children aged 14 years or below. ${ }^{1}$

Dental luxation and avulsion injuries account for $15 \%$ to $61 \%$ of all dental traumas to permanent teeth. ${ }^{4}$ It is an important public health concern as the treatment of such injuries is often complicated and requires specialist care. ${ }^{5,6}$ It also tends to occur at a young age during which growth and development take place and so long-term follow-up is needed.-7 The average number of dental visits because of trauma to a permanent tooth during 1 year has been shown to be much higher than that required for a bodily injury. ${ }^{6}$ Information on how and where dental trauma occurs, and the associated risk factors are important data that can be used to plan a preventive strategy. There is, however, little information about the epidemiology of dental trauma in children residing in Hong Kong. The aims of this retrospective study were to identify the major causes and types of dental luxation and avulsion injuries, and their associated factors in primary school children 


\section{香港小學生牙齒脫位和撕脫的研究 曹紹賢}

目的：研究香港小學生牙齒脱位和撕脱的主要原因和創傷類型, 以及 與此相關的因素。

設計：病例系列研究。

安排：香港新界區一所學童牙科診所。

患者：回顧研究 2005 年 11 月至 2012 年 10 月期間於上述牙科診所內的 牙齒紀錄。利用標準表格把學生受傷時客觀的臨床和影像結果和隨訪 檢查記錄下來。使用卡方檢驗和多項對數迴歸分析數據。

結果：記錄包括6歲至 14 歲共220名兒童 (355例) 牙齒脱位或撕脱的 病例, 男女比例為 1.8 比 1 。意外多數發生在 9 歲時。病例中半脱位為 最常見, 其次是牙齒震湯。上領中切牙是最受影響的牙齒。最常見是 因跌倒而導致牙齒受傷, 意外多數在學校內發生。共有199個有關學 生切牙關係的紀錄, 其中大部分屬I類。與另一個有關華籍人口切牙關 係的研究比較, 本研究的學生的III類咬合比例較高, III類咬合病例則 較少 $(\mathrm{P}<0.0001)$ 。

結論：香港小學生主要是因為跌倒引致牙齒脱位和撕脱。男孩發病率 高於女孩。II類切牙關係是一個顯著危險因素。

attending a school dental clinic in Hong Kong.

\section{Methods}

This retrospective study was carried out at Fanling School Dental Clinic that provides care for approximately 30000 primary school children in the Hong Kong New Territories East region. The study materials comprised dental records of patients with a history of dental luxation and/or avulsion injury

TABLE I. Indices used in the present study*

\begin{tabular}{|c|c|}
\hline Index & Description \\
\hline Teeth & FDI tooth number used \\
\hline Type of injury & $\begin{array}{l}\text { One of the six types of traumatic dental injury to } \\
\text { the periodontal tissues: concussion, subluxation, } \\
\text { extrusion, intrusion, lateral luxation, and avulsion }\end{array}$ \\
\hline Cold test & + or - \\
\hline Percussion sound & Normal / metallic / dull \\
\hline Tender to percussion & + or - \\
\hline Mobility & $\mathrm{Nil} / \mathrm{I} / \mathrm{II} / \mathrm{III}$ \\
\hline Discolouration & Nil / yellowish / grey / pink \\
\hline Periodontal pocket depth & Probing depth in $\mathrm{mm}$ \\
\hline X-ray: periapical & Specific radiographic findings \\
\hline X-ray: anterior occlusal & Specific radiographic findings \\
\hline Concomitant injury to teeth & Nil / fracture / pulp exposure \\
\hline Others & Other injury to orofacial area, eg lips \\
\hline
\end{tabular}

Abbreviation: $\mathrm{FDI}=$ Fédération Dentaire Internationale Numbering System

* Always include the two adjacent (apparently unaffected) teeth between November 2005 and October 2012. All dental luxation and avulsion injuries were logged in the electronic records using specific codes: an electronic search of records was performed using the same dental condition codes $(\mathrm{DC}=$ concussion, $\mathrm{DS}=$ subluxation, $\mathrm{DE}=$ extrusion, $\mathrm{DN}=$ intrusion, $\mathrm{DL}=$ lateral luxation, and $\mathrm{DA}=$ avulsion). All cases were examined clinically by at least one of the three attending paediatric dentists at the clinic who were experienced in treating children with dental trauma. All records were reviewed by one single examiner, the paediatric dentist in-charge of the clinic. Information was recorded in Microsoft Excel and data analysis was carried out using the Chi squared test and multinomial logistic regression with PASW Statistics 18 software (SPSS Inc, Chicago [IL], US). The level of significance was set at $\mathrm{P}<0.05$. To evaluate intra-examiner reliability, all selected records were reviewed by the same author 1 month after the original analysis and the findings of the two examinations compared for discrepancies.

\section{Clinical examinations}

Since November 2005, a standardised dental trauma form has been used in the clinic to facilitate followup care. The following parameters were recorded for patients who presented with dental luxation or avulsion injuries: date and time of injury, place where the injury occurred, cause of trauma, presence of other orofacial soft tissue injury, and the incisor relationship according to the British Standard Incisor Classification. ${ }^{8}$ The type of injury was classified according to the Andreasen modification of the World Health Organization classification, ${ }^{9}$ and included six types of injury to periodontal tissues (Table 1).

The adjacent apparently unaffected teeth on both sides were also included in the examination. For each tooth, objective clinical findings from the initial and follow-up examinations were recorded using the same standardised format and included the following: pulp sensitivity test; percussion tone; tenderness to percussion; tooth mobility; tooth colour; periodontal probing depths; and the presence of concomitant crown fractures and pulp exposure.

\section{Radiographic examinations}

An anterior occlusal radiograph together with periapical radiographs of the affected teeth were taken at the initial examination. At each follow-up appointment, periapical radiographs were repeated for the affected teeth. All periapical radiographs were taken using a standard film holder (Dentsply Rinn, Elgin [IL], US).

\section{Follow-up examinations}

All cases were followed up at regular intervals: 3 
weeks, 6 to 8 weeks, 6 months, and then annually from the time of injury. Patients with dental avulsion were also seen on days 7 to 10 for splint removal and root canal treatment if indicated.

\section{Results}

A total of 220 children with 355 teeth of dental luxation or avulsion injury were recorded during the study period. Their ages ranged from 6 to 14 years (mean age, 9.2 years; standard deviation, 1.7 years). To assess whether age was an important factor, children were divided into two age-groups: $58 \%(n=128)$ were aged 6 to 9 years and $42 \%(n=92)$ were 10 to 14 years at the time of injury. The male-to-female ratio was 1.8:1, with 141 boys and 79 girls. The gender difference in prevalence was more prominent in children aged 9 years or above. The peak occurrence was seen at the age of 9 years $(n=46)$, followed by the age of 8 years $(n=44)$ and 10 years $(n=38)$. Only one tooth was traumatised in 117 (53\%) children. The predominant traumatic dental injury was subluxation, followed by concussion (Table 2). Over $65 \%$ of teeth with concussion or subluxation also had crown fractures. Maxillary central incisors (295 teeth) were the most commonly affected, followed by maxillary lateral incisors (38 teeth) and mandibular incisors (20 teeth). The cause of injury was recorded in 219 cases (Table 3). Fall (62\%) was the predominant cause in both genders and age-groups, followed by collision (18\%) and cycling (15\%). There were no incidents of injury caused by motor vehicle accidents or fights. Statistical analysis using Chi squared test showed no significant difference in the cause of injury between genders $(\mathrm{P}=0.108)$ or between the two age-groups $(\mathrm{P}=0.193)$. The place where the injury occurred was recorded in 217 cases: most occurred at school (Table 4). Statistical analysis using Chi squared test showed a significant difference in the place of occurrence between genders (Chi squared=15.6, degrees of freedom=6, $\mathrm{P}<0.05)$, but no significant difference between the two age-groups $(\mathrm{P}=0.078)$. Multivariate analysis using multinomial logistic regression was then performed with gender and agegroup as independent variables and place of injury as a dependent variable. Because of the relatively small number of cases, injuries that occurred in the playground, street, swimming pool, and other places were grouped into one category named as other places in the analysis. Injury occurring at school was then compared with injuries that occurred at home, on a cycling path, or in other places. School was chosen as the reference because (1) it was the most common place where injury occurred; and (2) univariate analysis of individual places of injury using the Fisher's exact test showed no significant difference between genders regarding injuries at school whereas there were significant gender differences in injuries that occurred at home and on
TABLE 2. Types of dental luxation and avulsion injuries

\begin{tabular}{lccc}
\hline Type & $\begin{array}{c}\text { With crown } \\
\text { fracture }\end{array}$ & $\begin{array}{c}\text { Without crown } \\
\text { fracture }\end{array}$ & Total No. of teeth \\
\hline Concussion & 79 & 46 & 125 \\
\hline Subluxation & 120 & 58 & 178 \\
Extrusion & 12 & 9 & 21 \\
\hline Intrusion & 3 & 6 & 9 \\
Lateral luxation & 1 & 3 & 4 \\
\hline Avulsion & 4 & 14 & 18 \\
\hline Total & $\mathbf{2 1 9}$ & $\mathbf{1 3 6}$ & $\mathbf{3 5 5}$ \\
\hline
\end{tabular}

TABLE 3. Causes of dental luxation and avulsion injuries in relation to age and gender

\begin{tabular}{lrrrrr}
\hline Cause & $\begin{array}{c}\text { No. of } \\
\text { cases }\end{array}$ & Boys $^{*}$ & Girls & $\begin{array}{c}\text { Aged 6-9 } \\
\text { years }\end{array}$ & $\begin{array}{c}\text { Aged 10- } \\
\text { 14 years }\end{array}$ \\
\hline Fall & 136 & 82 & 54 & 80 & 56 \\
Collision & 39 & 26 & 13 & 25 & 14 \\
Cycling & 32 & 26 & 6 & 16 & 16 \\
Skateboard & 4 & 1 & 3 & 2 & 2 \\
Sport & 3 & 3 & 0 & 1 & 2 \\
Others & 5 & 2 & 3 & 1 & 4 \\
Total & $\mathbf{2 1 9}$ & $\mathbf{1 4 0}$ & $\mathbf{7 9}$ & $\mathbf{1 2 5}$ & $\mathbf{9 4}$ \\
\hline
\end{tabular}

* The differences between gender or between age-groups were not statistically significant (Chi squared test, $\mathrm{P}=0.108$ and 0.193 , respectively)

TABLE 4. Places where dental luxation and avulsion injuries occurred in relation to age and gender

\begin{tabular}{lccccc}
\hline Place & $\begin{array}{c}\text { No. of } \\
\text { cases }\end{array}$ & Boys $^{*}$ & Girls & $\begin{array}{c}\text { Aged 6-9 } \\
\text { yearst }\end{array}$ & $\begin{array}{c}\text { Aged 10- } \\
\text { 14 years }\end{array}$ \\
\hline School & 56 & 32 & 24 & 40 & 16 \\
Home & 33 & 15 & 18 & 22 & 11 \\
Cycling path & 32 & 26 & 6 & 16 & 16 \\
Playground & 24 & 20 & 4 & 14 & 10 \\
Street & 24 & 18 & 6 & 13 & 11 \\
Swimming pool & 12 & 7 & 5 & 5 & 7 \\
Others & 36 & 23 & 13 & 15 & 21 \\
Total & $\mathbf{2 1 7}$ & $\mathbf{1 4 1}$ & $\mathbf{7 6}$ & $\mathbf{1 2 5}$ & $\mathbf{9 2}$ \\
\hline
\end{tabular}

* The difference between genders was statistically significant (Chi squared test, $\mathrm{P}<0.05$ ) + The difference between the 2 age-groups was not statistically significant (Chi squared test, $\mathrm{P}=0.078$ )

a cycling path $(\mathrm{P}<0.05)$. The results of the regression showed that boys were more commonly affected than girls $(\mathrm{P}<0.05$; odds ratio $[\mathrm{OR}]=2.97$; $95 \%$ confidence interval $[\mathrm{CI}], 1.05-8.43)$ for injuries that occurred on a cycling path in comparison with injuries at school. In the same model, younger children were significantly less commonly affected than older 
TABLE 5. The distribution of incisor relationship in this study compared with a previous study of the general Chinese children population $^{10}$

\begin{tabular}{lccc}
\hline $\begin{array}{l}\text { Incisor } \\
\text { relationship* }\end{array}$ & $\begin{array}{c}\text { No. (\%) of cases in the present } \\
\text { study }\end{array}$ & $\begin{array}{c}\text { No. (\%) of cases in the general } \\
\text { Chinese population }{ }^{10}\end{array}$ & $\begin{array}{c}\text { Statistical difference } \\
\text { (Chi squared test) }\end{array}$ \\
\hline Class I & $126(63 \%)$ & $716(68 \%)$ & Chi squared=36.1 \\
Class II & $69(35 \%)$ & $202(19 \%)$ & Degrees of freedom=2 \\
Class III & $4(2 \%)$ & $132(13 \%)$ & P<0.0001 \\
Total & $\mathbf{1 9 9 ( 1 0 0 \% )}$ & $\mathbf{1 0 5 0 ( 1 0 0 \% )}$ & - \\
\hline
\end{tabular}

* Incisor relationship in accordance with the British Standard Incisor Classification ${ }^{8}$.

Class I:The lower incisal edges occlude with or lie immediately below the cingulum of the upper incisors

Class II:The lower incisal edge occludes behind the cingulum of the upper central incisors

Class III:The lower incisal edge occludes in front of the cingulum of the upper incisors

children $(\mathrm{P}<0.05 ; \mathrm{OR}=0.42 ; 95 \% \mathrm{CI}, 0.21-0.85)$ for injuries that occurred in other places compared with injuries at school.

Incisor relationship was registered in 199 cases: most were Class I (63\%) [Table 5]. Since such information was not available for the whole study, it was decided to use data from a previous study of the general Chinese population of children as a retrospective comparison group. ${ }^{10}$ Comparison of these two studies showed that there was a higher proportion of Class II and fewer Class III occlusions in the trauma group than in the general Chinese population. Statistical analysis showed a significant difference between the two population groups (Chi squared $=36.1$, degrees of freedom $=2, \mathrm{P}<0.0001$ ). Soft tissue injury occurred in the orofacial region in 87 children, and lips were involved in most instances (82\%). Intra-examiner reliability was evaluated and complete concordance of all data and parameters was found between the two evaluations that were 1 month apart.

\section{Discussion}

The difference in the proportion of causes of traumatic dental injury depends on various factors including culture, age-group, and population. ${ }^{11,12}$ In some developing countries, the most common cause of dental injury in children is violence. ${ }^{9}$ In this study, fall against a hard object such as the ground was the cause in over $60 \%$ of cases. This finding is in agreement with most other studies of traumatic dental injury in children. ${ }^{7,11-20}$ In a study of New Zealand children, fall was the most common cause in children aged 5 to 7 years, but collision became more common in the 8 - to 10 -year-old group. ${ }^{21}$ Nonetheless, such a trend was not observed in this study. Although dental injury due to cycling accidents was not uncommon in this study, this finding may be confounded by the fact that New Territories East has one of the busiest cycling path networks in Hong
Kong. ${ }^{2}$ The use of helmets offers little protection to the lower face and jaw. ${ }^{9}$ It has been suggested that modification of the helmet design to cover the lower face may be beneficial. There were few sportsrelated injuries observed in this study. This may be because high-risk contact sports, such as rugby and ice hockey, ${ }^{5}$ are not very popular among Hong Kong primary school children. Compulsory use of mouth guards in those who participate in such activities may also be a contributing factor. There was no case of trauma due to a road traffic accident; this may reflect the legal requirement in Hong Kong for all passengers to wear a car seatbelt.

In this study more boys than girls had dental luxation and avulsion injuries in accordance with the findings of most other studies., ${ }^{73-19,22-24}$ One probable reason for the gender difference is that boys take more risks and participate more in sports activities. Nonetheless this gender difference has narrowed in recent studies, possibly due to an increased interest in sports among girls, especially in western societies. ${ }^{5,11,21}$ In this study, a greater gender discrepancy in frequency of dental injury was observed in the older age-group, in accordance with the findings of Kania et al's study of elementary school children in the US. ${ }^{24}$

Previous studies of dental trauma in children have shown that most injuries occur between the age of 6 and 12 years., ${ }^{7,16-18}$ The present study population comprised primary school children attending a regional school dental clinic. The age of most primary school children in Hong Kong falls within the range of 6 to 12 years, and so most of the dental injuries for this group of children could be registered in this study. The peak occurrence of injury was seen in 9-year-olds, again in agreement with previous studies where the highest frequency of trauma to permanent dentition was observed in 9- to 10-year-olds. ${ }^{12,19}$ Nonetheless in studies from New Zealand ${ }^{21}$ and Iraq, ${ }^{14}$ the highest frequency of dental injury occurred in 5- to 7-year-olds. Glendor 
et $\mathrm{al}^{9}$ observed a marked increase in the incidence of dental injury in boys aged 8 to 10 years, with the incidence rather stable in girls. The same trend was also seen in this study. This may reflect the more vigorous play characteristics of boys in this agegroup than girls. ${ }^{9}$

The majority of dental injuries involve the anterior teeth, especially the maxillary central incisors. The maxillary lateral and mandibular incisors are affected less frequently. ${ }^{5,9}$ Similar findings were also observed in the present study. The more prominent position of the maxillary central incisors makes them more vulnerable to injury. In addition, Kania et $\mathrm{al}^{24}$ opined that maxillary incisors are more prone to injury than their mandibular counterparts because of the mandible's non-rigid connection to the cranial base. Most of the children in this study experienced trauma to only one tooth. This concurs with the findings from previous studies of dental injury in children. ${ }^{9,11,14,23,24}$ Noori and Al-Obaidi ${ }^{14}$ opined that when one tooth is traumatised, the majority of the force is dispersed and so no more teeth will be injured. ${ }^{14}$ It has been suggested that multiple tooth injuries are seen more often in more serious accidents such as motor vehicle accidents and violence. ${ }^{8,9,24}$ Concussion and subluxation together accounted for $85 \%$ of the cases in this study, in accordance with the findings of most previous studies on luxation and avulsion injuries in children. ${ }^{7,16,17,19,21}$ As the force and direction of impact determines the resultant type of injury, the findings from this study seem to suggest that most periodontal tissue injuries in Hong Kong primary school children are caused by more trivial incidents. ${ }^{9}$ Increased overjet and consequent incompetent lip closure is a significant risk factor to traumatic dental injury. ${ }^{7,9,13-15,22-24}$ In a study conducted in Iraq, 70\% of children who had a dental injury had increased overjet. ${ }^{14}$ In many other studies, most children who sustained a dental injury had normal overjet, yet the percentage of children with increased overjet was significantly higher in children with dental trauma than in the general population. , $^{7,13,22-24}$ Similar findings were also observed in the present study. The more prominent tooth position and the lack of a cushioning effect from the upper lip in Class II malocclusion make the maxillary incisors more prone to injury. ${ }^{14}$

In many previous studies, the predominant place of injury occurrence in school-aged children was home, followed by school and other public places. $^{9,13,21,22}$ In the present study, most injuries occurred at school. The second and third most common places of occurrence were home and cycling paths, respectively. This finding was in agreement with the population bodily injury survey of children aged 14 years or below in Hong Kong. ${ }^{1}$ One probable reason is that school children in Hong Kong have relatively more play-time at school than at home. In this study, $40 \%$ of children with a traumatic dental injury also suffered soft tissue injury in the orofacial region. This percentage was of similar magnitude to another study that involved a large proportion of children with dental luxation and avulsion injuries, ${ }^{17}$ but higher than a study with a high proportion of minor dental trauma such as simple fracture. ${ }^{12}$ This discrepancy may be because incidents that resulted in dental luxation or avulsion were usually more severe and could lead to more soft tissue damage.

One of the limitations of this study is its retrospective design. It is, however, extremely difficult to perform prospective trauma studies on a population basis. ${ }^{25}$ 'Grab' sampling was employed in this retrospective study, ie all patients treated in one clinic for dental luxation and/or avulsion injury were used in the sample. The conclusions from this study may therefore not be applicable to other parts of Hong Kong. To avoid inter-examiner error, all the records were reviewed by the most senior paediatric dentist in the clinic. The use of a standardised trauma form helps improve the accuracy of data collected during treatment. ${ }^{25}$ With the aid of a standardised form, the cause of dental injury was recorded in all but one case, and the place of trauma in all but three. This illustrates the importance of a standardised registry of dental traumatology.

This is the first epidemiological study of traumatic dental injury in children resident in Hong Kong and our data provide an important baseline for future comparison. Very often, school teachers are often the first to deal with an acute dental injury and it may be beneficial to educate them about the emergency care of children with dental trauma. For example, with avulsion injuries, where immediate management is critical for optimal healing, the teachers should be taught how to replant the tooth on site. If that could not be done, they should know how to store the avulsed tooth in an appropriate medium to prevent damage to the periodontal tissue. The effects of various factors on healing will be investigated and reported in a subsequent paper.

Dental traumas have social and economic impacts with regard to the treatment required but it is difficult to prevent dental injuries that are not sports-related. ${ }^{6,21}$ One option is to improve environmental factors to prevent falling at school and at home. Environmental and behavioural factors, however, were not included in this study so it is difficult to make conclusive suggestions in this regard. Further studies are warranted.

\section{Conclusion}

The causes and types of dental luxation and avulsion injuries in this group of Hong Kong children were similar to those of other studies, except that more injuries happened at school than at home. Most 
dental luxation and avulsion injuries in Hong Kong primary school children were caused by fall. Boys were more commonly affected than girls, and Class II incisor relationship was a significant risk factor. Motor vehicle accident or fight was not a common risk factor for dental injury in children. As most of the injuries occurred at school, it may be beneficial to educate primary school teachers about the emergency care of children with dental trauma.

\section{Acknowledgement}

The author thanks Dr Denise Fung for her statistical advice in this study.

\section{References}

1. Injury survey 2008. Hong Kong: Centre for Health Protection, Department of Health; 2010.

2. Chan CC, Cheng JC, Wong TW, et al. An international comparison of childhood injuries in Hong Kong. Inj Prev 2000;6:20-3.

3. Petersson EE, Andersson L, Sörensen S. Traumatic oral vs non-oral injuries. Swed Dent J 1997;21:55-68.

4. Andreasen FM, Andreasen JO. Luxation injuries of permanent teeth: general findings. In: Textbook and color atlas of traumatic injuries to the teeth. 4th ed. Oxford: Blackwell-Munksgaard; 2007; 372-403.

5. Glendor U. Epidemiology of traumatic dental injuries-a 12 year review of the literature. Dent Traumatol 2008;24:60311.

6. Andersson L. Epidemiology of traumatic dental injuries. Pediatr Dent 2013;35:102-5.

7. Zhang Y, Zhu Y, Su W, Zhou Z, Jin Y, Wang X. A retrospective study of pediatric traumatic dental injuries in Xi'an, China. Dent Traumatol 2014;30:211-5.

8. British standard incisor classification. Glossary of Dental Terms BS 4492. London: British Standard Institute; 1983.

9. Glendor U, Marcenes W, Andreasen JO. Classification, epidemiology and etiology. In: Textbook and color atlas of traumatic injuries to the teeth. 4th ed. Oxford: BlackwellMunksgaard; 2007: 217-54.

10. Lew KK, Foong WC, Loh E. Malocclusion prevalence in an ethnic Chinese population. Aust Dent J 1993;38:442-9.

11. Andreasen JO, Bakland LK, Matras RC, Andreasen FM. Traumatic intrusion of permanent teeth. Part 1. An epidemiological study of 216 intruded permanent teeth Dent Traumatol 2006;22:83-9.

12. Eyuboglu O, Yilmaz Y, Zehir C, Sahin H. A 6-year investigation into types of dental trauma treated in a paediatric dentistry clinic in Eastern Anatolia region, Turkey. Dent Traumatol 2009;25:110-4.

13. Bendo CB, Paiva SM, Oliveira AC, et al. Prevalence and associated factors of traumatic dental injuries in Brazilian schoolchildren. J Public Health Dent 2010;70:313-8.

14. Noori AJ, Al-Obaidi WA. Traumatic dental injuries among primary school children in Sulaimani city, Iraq. Dent Traumatol 2009;25:442-6.

15. Taiwo OO, Jalo HP. Dental injuries in 12-year-old Nigerian students. Dent Traumatol 2011;27:230-4.

16. Sandalli N, Cildir S, Guler N. Clinical investigation of traumatic injuries in Yeditepe University, Turkey during the last 3 years. Dent Traumatol 2005;21:188-94.

17. Díaz JA, Bustos L, Brandt AC, Fernández BE. Dental injuries among children and adolescents aged 1-15 years attending to public hospital in Temuco, Chile. Dent Traumatol 2010;26:254-61.

18. Toprak ME, Tuna EB, Seymen F, Gençay K. Traumatic dental injuries in Turkish children, Istanbul. Dent Traumatol 2014;30:280-4.

19. Atabek D, Alaçam A, Aydintuğ I, Konakoğlu G. A retrospective study of traumatic dental injuries. Dent Traumatol 2014;30:154-61.

20. Hecova H, Tzigkounakis V, Merglova V, Netolicky J. A retrospective study of 889 injured permanent teeth. Dent Traumatol 2010;26:466-75.

21. Chan YM, Williams S, Davidson LE, Drummond BK. Orofacial and dental trauma of young children in Dunedin, New Zealand. Dent Traumatol 2011;27:199-202.

22. Glendor U. Aetiology and risk factors related to traumatic dental injuries-a review of the literature. Dent Traumatol 2009;25:19-31.

23. Zaragoza AA, Catalá M, Colmena ML, Valdemoro C. Dental trauma in schoolchildren six to twelve years of age. ASDC J Dent Child 1998;65:492-4,439.

24. Kania MJ, Keeling SD, McGorray SP, Wheeler TT, King GJ. Risk factors associated with incisor injury in elementary school children. Angle Orthod 1996;66:423-32.

25. Andersson L, Andreasen JO. Important considerations for designing and reporting epidemiologic and clinical studies in dental traumatology. Dent Traumatol 2011;27:269-74. 